\title{
PENANAMAN NILAI-NILAI KARAKTER ISLAMI MELALUI PROGRAM BPI (BINA PRIBADI ISLAM) DI SMPIT AL KHOIRIYAH GARUT
}

\author{
Wati Karmila \\ STAI DA Muhammadiyah Garut \\ e-mail : staidamgarut@ymail.com.com \\ Uci Tarmana \\ STAI DA Muhammadiyah Garut \\ e-mail: ucitarmana@gmail.com
}

\begin{abstract}
Abstrak
Tujuan penelitian ini secara umum untuk menganalisis dan mengetahui penanaman nilainilai karakter Islami melalui program BPI (bina pribadi islam) di SMPIT Al khoiriyah Garut. Penelitian ini menggunakan pendekatan kualitatif dengan metode deskriptif analitis. Teknik pengumpulan data menggunakan observasi, wawancara, dan studi dokumentasi. Sedangkan analisis datanya menggunakan reduksi data, display data dan kongklusi data. Hasil penelitian ini menunjukkan bahwa: 1) Tujuan Penanaman Nilai-nilai Karakter Islami Melalui Program BPI (Bina Pribadi Islam) di SMP Islam Terpadu Al-Khoiriyyah, yaitu untuk menumbuhkan kebiasaan Islami dan akhlak yang baik yang sesuai tuntunan ajaran Islam bagi siswa secara kontinu dalam kehidupan sehari-hari agar nantinya siswa siap terjun ke masyarakat sebagai generasi unggul yang cerdas, mandiri dan religius/spiritual. Sedangkan programnya: Pembelajaran Tahsinul dan Tahfidzul Qur'an, Program Ekstrakurikuler, Penambahan Muatan lokal, Kegiatan Sekolah Orangtua, dan Program Pesantren yang di asramakan 2) Implementasinya dengan menggunakan pendekatan pembinaan keteladanan, pembinaan dengan pembiasaan, dan pembinan dengan nasihat yang masuk kedalam program, dan masuk dalam waktu pembelajaran 3) Hasilnya berdampak positif dengan bertutur kata dengan bahasa yang sopan dan berbuat baik terhadap orang lain, senantiasa menutup aurat, belajar amar ma'ruf nahi mungkar, melakukan wudhu dengan tertib dan benar, melaksanakan shalat berjama'ah, menghafal al-Qur`an beserta terjemahnnya dan hadist Nabi yang di aplikasinya dalam kehidupan sehari-hari.
\end{abstract}

Kata Kunci : Penanaman Nilai-nilai, Karakter Islami, BPI (Bina Pribadi Islam)

\section{Abstract}

The purpose of this study in general is to analyze and find out the cultivation of Islamic character values through the BPI (Islamic personal development) program at SMPIT Al Khoiriyah Garut. This study uses a qualitative approach with analytical descriptive method. Data collection techniques using observation, interviews, and documentation studies. While the data analysis uses data reduction, data display and data conclusions. The results of this study indicate that: 1) The purpose of instilling Islamic Character Values through the BPI (Islamic Personal Development) Program at the Al-Khoiriyyah Integrated Islamic Junior High School, namely to cultivate Islamic habits and good morals that are in accordance with the guidance of Islamic teachings for students continuously in everyday life so that later students are ready to enter the community as a superior generation who is intelligent, independent and religious/spiritual. While the programs are: Tahsinul and Tahfidzul Qur'an Learning, Extracurricular Programs, Addition of Local Content, Parents School Activities, and Boarding School Programs that are in dormitories 2) Implementation using exemplary coaching approaches, oaching with habituation, and coaching 
with advice that goes into the program and included in the learning time 3) The results have a positive impact by speaking in polite language and doing good to others, always covering the genitals, learning amar ma'ruf nahi munkar, doing ablution in an orderly and correct manner, praying in congregation, memorizing Al-Qur'an and its translation and the hadith of the Prophet which are applied in everyday life.

\section{Keywords: Instilling Values, Islamic Character, BPI (Islamic Personal Development)}

\section{PENDAHULUAN}

Fenomena merosotnya karakter berbangsa di tanah air dapat disebabkan lemahnya pendidikan karakter dalam meneruskan nilai-nilai kebangsaan pada saat alih generasi. Di samping itu, lemahnya implementasi nilai-nilai berkarakter di lembaga-lembaga pemerintahan dan kemasyarakatan ditambah berbaurnya arus globalisasi telah mengaburkan kaidah-kaidah moral budaya bangsa yang sesungguhnya bernilai tinggi. Akibatnya, prilaku-prilaku tidak normatif semakin jauh merasuk ke dalam dan berakibat merusak kehidupan berbangsa.

Abuddin Nata menggambarkan bahwa gejala keruntuhan moral dewasa ini sudah benar-benar mengkhawatirkan. Kejujuran, kebenaran, keadilan, tolong menolong, dan kasih sayang sudah tertutup oleh penyelewengan, penipuan, penindasan, saling menjegal, dan saling merugikan. Banyak terjadi adu domba dan fitnah, menjilat, menipu, mengambil hak orang lain sesuka hati, dan perbuatan-perbuatan maksiat lainnya (Abuddin Nata, 2003:197). Semua itu menjadi alasan mengapa pendidikan karakter penting diterapkan dalam dunia pendidikan (Johansyah, 2018).

Dengan adanya beragam fenomena yang semakin krisis tentang karakter individu dan kurang pekanya orang tua dalam mendidik anak, maka penting untuk diadakan sebuah upaya untuk dapat menumbuhkan karakter pada anak, khususnya karakter yang Islami, supaya anak dapat tumbuh dan berkembang dengan karakter yang Islami (Mhd. Aulia Firman Puldri, 2017).

Dalam Islam, pembangunan karakter merupakan masalah fundamental untuk membentuk umat yang berkarakter.
Pembangunan karakter dibentuk melalui pembinaan akhlakul karimah (akhlak mulia); yakni upaya transformasi nilai-nilai qur'ani kepada anak yang lebih menekankan aspek afektif atau wujud nyata dalam amaliyah seseorang (Judiani., 2010).

Salah satu upaya penanaman nilai-nilai karakter Islami peserta didik di lingkungan SMP IT Al hoiriyah,yaitu dengan adanya Bina Pribadi Islam (BPI). Bina Pribadi Islam ini merupakan program yang dirancang oleh yayasan Islam terpadu di seluruh Indonesia. Bina Pribadi Islam adalah sebuah proses pendampingan untuk peningkatan hubungan antara anak dan orang tua, teman sebaya dan guru yang multidimensional guna membantu anak menghadapi tantangan dan masalah dalam kesehariannya. Pada dasarnya inti dari Bina Pribadi Islam yaitu suatu pembinaan Islami.

Tujuan dilaksanakan Bina Pribadi di SMPIT Al Khoiriyah yaitu untuk meningkatkan kecerdasan spiritual pada peserta didik agar tidak terjerumus dalam penyimpangan terhadap sikap keberagamaan dan sosial, mendampingi dan mengarahkan peserta didik dalam mengkaji dan mengaplikasikan nilai-nilai keIslaman dalam dirinya sehingga memiliki budi pekerti atau akhlak mulia yang ditunjang dengan penguasaan ilmu dengan baik yang kemudian mampu mengamalkan ilmunya dengan tetap dilandasi oleh iman yang benar.

Berdasarkan studi lapangan di SMPIT Al Khoiriyah, walaupun piha sekolah sudah menanamkan nilai-nilai karakter Islami melalui program Bina Pribadi Islam (BPI) di sekolah, tapi masih saja terdapat peserta didik yang berprilaku kurang sopan pada guru, bertutur kata yang tidak santun bahkan masih ada yang suka bolos pada saat jam 
pelajaran berlangsung dan malas dalam belajar.

Menurut Jamal Ma'mur Asmani (2017), "Penanaman karakter menjadi kebutuhan mendesak mengingat demoralisasi dan degradasi pengetahuan sudah sedemikian akut menjangkiti bangsa ini di semua lapisan masyarakat. Penanaman karakter di sekolah diharapkan mampu membangkitkan kesadaran bangsa ini untuk membangun pondasi kebangsaan yang kokoh" (Wasit Aulawi, 2017).

Selain itu menurut Marzuki, "penanaman karakter harus mampu mengemban misi pembentukan karakter sehingga peserta didik dan para lulusan lembaga pendidikan dapat berpartisipasi dalam mengisi pembangunan dengan baik dan berhasil tanpa meninggalkan nilai-nilai karakter mulia" (Marzuki., 2015:34).

Senada dengan pendaat di atas, Zubaedi (2011) menyatakan bahwa, pendidikan karakter adalah "usaha sengaja (sadar) untuk mewujudkan kebajikan, yaitu kualitas kemanusiaan yang baik secara objek, bukan hanya baik untuk individu perseorangan, tetapi juga baik untuk masyarakat secara keseluruhan" (Zubaedi, 2011:15). Pendidikan karakter dimaknai sebagai suatu proses pendidikan secara holistis yang menghubungkan dimensi moral dengan ranah sosial dalam kehidupan peserta didik sebagai pondasi bagi terbentuknya generasi yang berkualitas yang mampu hidup mandiri dan memiliki prinsip suatu kebenaran yang dapat dipertanggung jawabkan (Habibah, 2015).

Untuk memperkuat penelitian yang akan dilakukan, beberapa penelitian terdahulu yang berkaitan dengan penelitian ini diantaranya kajian yang dilakukan oleh Fani Fadliyani, Yosep Farhan dan Muhamad Aris Munawar (2020), dengan judul "Implementasi Bina Pribadi Islam (BPI) dalam Membina Akhlak Peserta Didik di Sekolah Dasar Inspiratif Al-Ilham Kota Banjar",yang hasilnya menunjukan bahwa : Hasil Bina Pribadi Islam (BPI) dalam membina akhlak peserta didik di SD Inspiratif Al-Ilham Kota Banjar sudah cukup baik, dimana peserta didik sudah mampu melaksanakan apa yang sudah disampaikan oleh guru atau murobbinya. Bahwasanya memang terbukti didukung dengan adanya Bina Pribadi Islam yang sudah sangat baik, sehingga hasil dari peserta didik juga sudah cukup baik, untuk menunjang akhlak peserta didik yang mana terdapat pada indikator- indikator Bina Pribadi Islam dalam pembinaan akhlak peserta didik. Sehingga tujuan dalam membina dan memperbaiki akhlak peserta didik sudah cukup optimal.

Berdasarkan pemaaran gap di atas peneliti ingin mengetahui lebih lanjut bagaimana pelaksanaan Penanaman Nilainilai Karakter Islami Melalui Program BPI (Bina Pribadi Islam) di SMP Islam Terpadu Al-Khoiriyyah, sehingga menganggap penting untuk mengadakan penelitian ini. Pembuktian yang rasional tentang seberapa besar pengaruh faktor-faktor tersebut diharapkan dapat terpetakan secara tepat. sehingga hal ini perlu ditindak lanjuti dengan memformulasikan dalam sebuah penelitian yang akan peneliti lakuna ini.

\section{METODOLOGI}

Penelitian ini dilakukan pada SMPIT Al Khoiriyah Garut tentang Penanaman Nilainilai Karakter Islami Melalui Program BPI (Bina Pribadi Islam). Adapun metode penelitian yang digunakan dalam penelitian ini adalah penelitian kualitatif, dengan pendekatan deskriptif analitis. Penelitian kualitatif adalah proses pemecahan suatu masalah yang berhubungan dengan manusia dengan bertujuan untuk memahami fenomena yang terjadi, dengan latar belakang sosial maupun kultural. Penelitian ini dilakukan dengan tidak menganalisa angka dan melaporkan deskripsi hasil penelitian secara detail (Pertiwi \& Weganofa, 2015: 19).

Pada pendekatan kualitatif arah dan fokus suatu penelitian adalah membangun teori dari data atau fakta, mengembangkan sintesa interaksi dan teori-teori yang dibangun dari fakta-fakta mendasar (grounded) mengembangkan pengertian, dan sebagainya yang berarti tiap langkah mengutamakan proses apa adanya dan tanpa dibatasi norma- 
norma, rumus, dan yang lainnya (Musianto, 2002). Tujuan utama penelitian kualitatif yaitu untuk menangkap arti (meaning/ understanding) yang terdalam atas suatu kejadian, gejala, fakta atau masalah tertentu dan bukan untuk mempelajari atau membuktikan adanya hubungan sebab akibat dari suatu masalah atau peristiwa (Raco, 2010:106).

\section{HASIL DAN PEMBAHASAN}

Penelitian ini bertujuan untuk mengetahui tentang penanaman nilai-nilai karakter Islami melalui program BPI (Bina Pribadi Islam di SMPIT Al Koiriyah Garut. Berdasarkan hasil penelitian diketahui bahwa

\section{Tujuan dan Program Penanaman Nilai-nilai Karakter Islami Melalui Program BPI (Bina Pribadi Islam) di SMP Islam Terpadu Al-Khoiriyyah}

SMP Islam Terpadu Al-Khoiriyyah Garut merupakan tingkat satuan pendidikan sekolah menengah Islam yang memiliki suatu program pembinaan akhlak peserta didik yakni sebuah program yang bernama Bina Pribadi Islam. Pada Bina Pribadi Islam ini, peserta didik diarahkan serta di didik dalam rangka membentuk seorang pribadi yang Islami, berjiwa Islami, dan berkarakter Islami.

Bina Pribadi Islam merupakan kegiatan pembinaan kearah terbentuknya akhlak dan kepribadian Islam yang dicerminkan dalam pola fikir, pola sikap, dan pola prilaku seharihari. Pembinaan akhlak ini mengarah kepada upaya pembentukan perilaku santun, bersih, amanah, peduli dan bertanggung jawab (Nurwahid, 2010: 602). Bina Pribadi Islam adalah program yang dirancang oleh yayasan Islam terpadu diseluruh Indonesia. Bina Pribadi Islam ini merupakan program pendalaman pendidikan Islam ditingkat sekolah dasar Islam terpadu hingga sekolah menengah yang berada dibawah naungan Jaringan Sekolah Islam Terpadu Indonesia dalam rangka menguatkan pelaksanaan pembinaan peserta didik dalam membentuk peserta didik yang barakhlak \& berkakter Islami (Aisah. S, 2019).
Hadirnya Bina Pribadi Islam di SMP Islam Terpadu Al-Khoiriyyah Garut ini yaitu merupakan salah satu program yang masuk dalam kurikulum pembelajaran yang ada disekolah tersebut, dimana Bina Pribadi Islam ini merupakan sebuah Program sekaligus kurikulum dan masuk dalam proses belajar mengajar. Seperti yang terungkap pada saat hasil wawancara dengan semua civitas academika dan studi dokumentasi dari Kurikulum SMP Islam Terpadu AlKhoiriyyah, bahwa tujuan Penanaman Nilainilai Karakter Islami Melalui Program BPI (Bina Pribadi Islam) di SMP Islam Terpadu Al-Khoiriyyah, yaitu untuk menumbuhkan kebiasaan Islami dan akhlak yang baik yang sesuai tuntunan ajaran Islam bagi siswa secara kontinu dalam kehidupan sehari-hari agar nantinya siswa siap terjun ke masyarakat sebagai generasi unggul yang cerdas, mandiri dan religius/spiritual. Spiritual mencakup etika, budi pekerti dan moral sebagai perwujudan dari Pendidikan Agama Islam serta Pendidikan Pancasila dan Kewarganegaraan (PPKn). (Hasil observasi pada SMP Islam Terpadu AlKhoiriyyah, Garut, pada tanggal 5 Desember 2019, pukul 09. 00 WIB).

Mulyasa (2012:14), mengungkapkan bahwa ada 8 jurus yang perlu diperhatikan dalam menyukseskan pendidikan karakter di sekolah, yaitu: 1) Memahami Hakikat Pendidikan Karakter, 2) Sosialisasikan dengan Tepat, 3) Ciptakan Lingkungan yang Kondusif, 4) Dukung dengan Fasilitas dan sumber belajar yang memadai, 5) Tumbuhkan disiplin Peserta Didik, 6) Pilih Kepala Sekolah yang Amanah 7) Wujudkan Guru yang dapat Digugu dan Ditiru, 8). Libatkan Seluruh Warga Sekolah (Mulyasa, 2012:14).

Adapun upaya yang dilakukan oleh pihak sekolah dalam menanamkan nilai-nilai karakter Islami melalui program BPI (Bina Pribadi Islam) di SMP Islam Terpadu AlKhoiriyyah, yaitu dengan melaksanakan beberapa program BPI (Bina Pribadi Islam), diantaranya yaitu : 


\section{1) Pembelajaran Tahsinul dan Tahfidzul Qur'an}

Program Tahsinul dan Tahfidzul Qur'an adalah pembiasaan menghafal al-Qur'an terutama menghafal Surah-surah sampe juz 30. Dengan menggunakan metode pembiasaan dilakukan secara kontinu setiap hari, teratur dan terprogram dengan sistim setoran. Tujuannya, agar peserta didik terbiasa membaca al-Quran dengan tartil baik dan benar. Program ini spesial untuk memperbaiki tahsin, tajwid dan makhorijul huruf dengan metode talaqqi dan menanamkan gemar membaca al-Qur'an serta mengetahui arti dan maknanya. Sehingga SMP ini sering menjadi pemenang dalam lomba baik tingkat jawa barat atau nasional.

\section{2) Program Ekstrakurikuler}

Kegiatan Ekstra Kurikuler adalah kegiatan pendidikan di luar mata pelajaran dan pelayanan konseling untuk membantu pengembangan peserta didik sesuai dengan kebutuhan, potensi, bakat, dan minat mereka melalui kegiatan yang secara khusus diselenggarakan oleh pendidik dan atau tenaga kependidikan yang berkemampuan dan berkewenangan di sekolah. Semua ektrakurikuler mempunyai peran dalam pendidikan karakter. Implementasi ektrakulikuler yang ada di SMP Islam Terpadu Al-Khoiriyyah diantaranya, Rohis, PMR, Paskibra, Pramuka, OSIS, kreasi seni, KIR (Kelompok Ilmiah Remaja) dan keputrian. Sehingga melalui kegiatan ini diarahkan untuk membentuk mental dan karakter siswa, sehingga memiliki kepedulian dan solidaritas sosial yang tinggi serta siap berkorban demi kepentingan orang lain.

\section{4) Penambahan Muatan lokal}

Penambahan muatan lokal Bahasa Sunda, Bahasa Inggris, Bahasa Arab, Komputer dan Pendidikan lingkungan hidup Muatan lokal diartikan sebagai program pendidikan yang isi dan media penyampaiannya dikaitkan dengan lingkungan alam, lingkungan sosial dan lingkungan budaya serta kebutuhan pembangunan daerah setempat yang perlu diajarkan kepada siswa.
Muatan lokal adalah kegiatan kurikuler untuk mengembangkan kompetensi yang disesuaikan dengan ciri khas dan potensi daerah, termasuk keunggulan daerah, yang materinya tidak dapat dikelompokkan ke dalam mata pelajaran yang ada. Substansi mata pelajaran muatan lokal ditentukan oleh satuan pendidikan yang disesuaikan dengan karakteristik daerah masing-masing. Adapun muatan lokal yang ada di SMP Al Khoiriyah diantaranya Bahasa Sunda, Bahasa Inggris, Bahasa Arab, Komputer dan Pendidikan lingkungan hidup. Kegiatan ini seringkali menjadi Juara baik tingkat daerah atau nasional.

\section{4) Kegiatan Sekolah Orangtua}

Program Madrasah Orang Tua/ sekolah orangtua yang di agendakan setiap 1 Triwulan menjadi solusi bagi sekolah untuk menyamakan Visi dan Misi dengan Orang tua dalam membangun pendidikan karakter Islami pada anak-anak di sekolah kami. Sekolah Orangtua bertujuan sebagai wadah komunikasi antara orangtua dengan pihak sekolah. Khusus orangtua, sejak awal pendaftaran sudah menyamakan pendapat mengenai kurikulum pendidikan karakter berbasis Islami di sekolah. Rapat Evaluasi bulanan antara Tim Sekolah, Tim BK, dan Wali kelas mengenai perkembangan anak dan permasalah-permasalahan yang terjadi pada anak menjadi salah satu solusi juga bagi sekolah tentunya.Sehingga melalui program Bina Pribadi Islam untuk mengawal siswa terhadap apapun yang dilakukan, baik di sekolah maupun di luar sekolah.

\section{asramakan \\ 5) Program Pesantren yang di}

Program Pesantren yang di asramakan ini merupakan salah satu program unggulan yang dimiliki oleh SMP IT Al Khoiriyah. Program Pesantren yang di asramakan ini diperuntukan bagi siswa pilihan yang lulus seleksi di awal masuk. Kegiatan di pondok pesantren ini menyelenggarakan kegiatan keterampilan khusus agama Islam, kegiatan keagamaan, sepeti tahfidz (hafalan) AlQur'an dan majelis taklim, yang kurikulumnya bersinergi dengan sekolah. Siswa yang diterima di pesantren ini hanya 
bisa menampung 40 siswa, jadi tidak semua bisa masuk pesantren tapi diseleksi dulu di awal masuk.

\section{Implementasi Progam Penanaman Nilai-nilai Karakter Islami Melalui Program BPI (Bina Pribadi Islam) di SMP Islam Terpadu Al-Khoiriyyah}

SMP Islam Terpadu Al-Khoiriyyah merupakan salah satu Sekolah menengah pertama yang memadukan antara sekolah umum dengan sekolah Islam Terpadu, mengintegrasikan kurikulum Nasional dengan Nilai-Nilai Islami yang mengacu pada standarisasi mutu atau menganut pada JSIT Indonesia ( Jaringan Sekolah Islam Terpadu). SMP Islam Terpadu Al-Khoiriyyah telah menciptakan sebuah keseimbangan serta keselarasan yakni memadukan antara ilmu pengetahuan dunia dengan ilmu pengetahuan akhirat serta visi dan misi sekolah yang Islami dan berkompetensi.

Berdasarkan dari hasil wawancara dengan Bapak Rifki, B, S.Pd selaku waka kesiswaan SMP Islam Terpadu Al-Khoiriyyah sekaligus penanggung jawab BPI, mengatakan bahwa Penanaman Nilai-nilai Karakter Islami Melalui Program BPI (Bina Pribadi Islam) peserta didik disekolahnya menggunakan pendekatan keteladanan, pembinaan dengan pembiasaan, dan pembinan dengan nasihat yang masuk kedalam program, dan masuk dalam waktu pembelajaran. Menurut Nasution \& Manurung dalam buku Patologi Sosial dan Pendidikan Islam Keluarga. Pembinaan karakter yaitu pembinaan yang berhubungan tentang, pembinaan dengan menggunakan keteladanan, pembinaan dengan pembiasaan, dan pembinan dengan nasihat.

a. Pembinaan dengan keteladanan

Pembinaan dengan metode keteladanan berarti pembinaan dengan memberi contoh. Baik berupa tingkah laku, sifat, cara berfikir dan sebagainya. Hal itu karena dalam belajar manusia pada umumnya, lebih mudah menangkap yang kongkrit dari pada yang abstrak. Jadi sudah jelas bahwa metode pembinaan dengan keteladanan merupakan hal yang paling berhasil dalam proses pembinaan akhlak peserta didik (Juraini, 2018).

Dari hasil wawancara yang telah penulis lakukan bahwasanya, dalam membina Bina Pribadi Islam (BPI) pada peserta didik SMPIT Al Khoiriyah Garut juga sangat menekankan pada pemberian keteladanan atau memberi contoh yang baik untuk peserta didik. Karena seorang guru adalah panutan yang ditiru perilaku dan lisan nya serta menjadi suri tauladan bagi para peserta didik. Caranya yaitu oleh seorang murobbi atau guru pada Bina Pribadi Islam yakni dengan cara ceramah saat BPI berlangsung, selain itu juga dengan keteladanan langsung dari seorang pendidik. Mendidik peserta didik dengan tauladan adalah salah satu cara yang paling efektif karena memberikan keteladanan yang baik, sehingga peserta didik pun akan lebih mudah untuk meniru atau mengikutinya, dari semua apa yang dia lihat dari seorang pendidik.

b. Pembinaan dengan Pembiasaan

Metode pembiasaan kepada peserta didik terutama dalam hal akhlak, etika, sopan santun berbicara dll, dapat diaplikasikan atau diamalkan serta tertanam pada setiap diri peserta didik dalam kehidupan sehari-hari. Menerapkan sebuah metode kebiasaan ini adalah salah satu cara yang akan dapat menumbuhkan akhlakul karimah/ akhlak yang mulia kepada peserta didik, jiwa yang bersih, serta etika yang sesuai dalam syari'at Islam. Berdasarkan hasil observasi di SMPIT Al Khoiriyah Garut, peserta didik sudah dibiasakan untuk melakukan sholat berjamaah, sholat sunnah dhuha dan qiyamullail, membaca dzikir setiap selesai sholat dan lain-lain.

Pembiasaan merupakan sesuatu yang sengaja dilakukan secar berulang-ulang agar sesuatu itu dapat menjadi kebiasaan. Pembiasaan menempatkan manusia sebagai sesuatu istimewa, yang dapat menghemat kekuatan, karena akan menjadi kebiasaan yang melekat dan spontan, agar kegiatan itu dapat dilakukan dalam setiap pekerjaan. Maka pembiasaan dapat diterapkan dalam proses pembentukan karakter peserta didik (Furqun Hidayatullah, 2010:39). 


\section{c. Pembinaan dengan Nasehat}

Metode pembinaan akhlak melalui pemberian nasehat dapat menanamkan pengaruh yang baik dalam jiwa, apabila digunakan dengan cara yang dapat mengetuk qalbu. Sementara itu cara pemberian nasehat kepada peserta didik, para pendidik menekankan pada ketulusan dan disertai dengan keihklasan. Dari penjelasan diatas maka seorang guru harus menasehati peserta didik dengan cara yang lembut ataupun cara yang tepat. Sehingga akan terbuka pintu hati peserta didik untuk berbuat kebaikan dan peserta didik akan lebih menerima nasehat atau arahan dari gurunya (Juraini, 2018).

Dari hasil observasi yang penulis lakukan di SMPIT Al Khoiriyah Garut, setelah mereka mendapatkan nasehat dan pemahaman setiap harinya dari guru atau murobbi, mereka menerapkannya langsung dalam kehidupan sehari- hari. Seperti nasehat yang diulang-ulang bahwa kita harus saling berbagi, maka telah terlihat oleh penulis bahwa peserta didik memang selalu saling berbagi dan contoh lain sebagainnya. Selain itu, pembinaan karakter melalui nasehat sangat berkaitan dengan keteladanan dan pembiasaan. Jadi apabila nasehat sudah diberikan maka secara sistematis akan di aplikasikanya dalam bentuk keteladanan dan pembiasaan dalam kehidupan sehari-hari.

\section{Hasil Penanaman Nilai-nilai Karakter Islami Melalui Program BPI (Bina Pribadi Islam) di SMP Islam Terpadu Al-Khoiriyyah}

Dari hasil wawancara dengan Bapak Dalpa, D.P, S.Pd, selaku guru BK di SMP IT Al Khoiriyah Garut, beliau mengatakan bahwa Bina Pribadi Islam itu masuk kedalam pembelajaran, dan masuk ke dalam mata pelajaran, serta merupakan program wajib di. Penulis dapat menganalis sesuai dengan hasil serta saat terjun dilapangan maupun observasi di SMP IT Al Khoiriyah Garut, bahwa sekolah telah berupaya semaksimal mungkin dalam membina karakter para peserta didik dengan program-program sekolah yang sangat menunjang, segenap guru-guru juga sudah berupaya semaksimal mungkin dalam membina dan mendidik peserta didik dengan karakter Islami. Program telah dilaksanakan dan kewajiban serta tanggung jawab seorang guru telah dijalankan, tetapi implementasi dari peserta didik nya berbeda-beda, seiring berjalanya waktu dengan adanya program sekolah dalam membina karakter peserta didik.

Penulis menganalisis data yang diperoleh berdasarkan hasil observasi dan wawancara, secara umum mengenai hasil dari Bina Pribadi Islam dalam membina karakter peserta didik di SMP IT Al Khoiriyah Garut yaitu berdampak pada :

a) Bertutur kata dengan bahasa yang sopan dan berbuat baik terhadap orang lain

Saat melakukan observasi penulis melihat bahwasanya peserta didik yang berada dilingkungan SMP IT Al Khoiriyah Garut ketika bergaul, bertutur kata cukup baik, serta sangat menghormati dengan orang yang lebih tua, terutama ketika seorang peniliti datang langsung ke SMP IT Al Khoiriyah Garut melihat di kelas secara langsung dan lingkungan sekolah terdapat seluruh peserta didik sangat ramah, senyum serta menyapa dengan sopan dan santun, tidak ada kegaduhan dari peserta didik, hanya dari beberapa peserta didik saja yang berbicara nya dengan nada yang keras atau kasar, tetapi mayoritas peserta didik memiliki tutur kata yang sangat baik serta sopan dan santun.

b) Senantiasa Menutup Aurat

SMP IT Al Khoiriyah Garut, baik aparatur sekolah/ segenap dewan guru dan seluruh peserta didik yang berada di luar lingkup umum, semua nya wajib menutup aurat. Dalam hal menutup aurat, seluruh guru perempuanya sudah mengenakan hijab yang berdasarkan contoh dari syari'at islam, yakni hingga menutupi dada, dan ukuranya cukup besar hingga menutupi di bagian bawah pusar. Penulis telah mengamati, bahwasanya ketika berpakaian peserta didik sudah sangat rapih, sesuai dengan peraturan yang ada di SMP IT Al Khoiriyah Garut, mengenakan hijab nya sudah hampir mengikuti contoh dari tauladan guru, peserta didik perempuan telah diberikan contoh dan aktualisasi dari pendidik tentang bahwasanya seorang wanita/ perempuan itu 
hukumnya sangat wajib harus menutup auratnya dalam kehidupanya sehari-hari, baik dilingkungan sekolah maupun dilingkungan masyarakat.

c) Belajar amar ma'ruf nahi mungkar

Berdasarkan observasi, peserta didik sudah belajar materi tentang amar ma'ruf nahi mungkar, terlihat mayoritas peserta didik sudah mengerjakan hal-hal yang baik seperti, giat dalam belajar, tolong menolong, sopan santun, tidak bersuudzon terhadap orang lain, dan juga tidak suka berbisik-bisik ketika para peserta didik sedang berkumpul.

d) Melakukan wudhu dengan tertib dan benar

Pada pembelajaran Bina Pribadi Islam seluruh peserta didik belajar tentang bagaimana cara berwudhu yang tertib dan juga benar. Semua pelajaran itu disampaikan langsung oleh guru atau murobbi tiap kelas, bahkan di SMP IT Al Khoiriyah Garut, ini ketika pembelajaran bukan hanya menyampaikan materinya saja, namun memperaktekannya langsung supaya para peserta didik dapat memahaminya. Selain itu ketika akan melaksanakan sholat berjamaah disekolah, setiap peserta didik ketika berwudhu selalu dipantau oleh guru yang bertugas, dari mulai berwudhu sampai dengan membaca do'a setelah berwudhu. Ketika ada yang belum benar langsung ditegur dan diajarkan.

e) Melaksanakan Shalat Berjama'ah

Dari hasil observasi yang telah penulis lakukan, bahwasanya terlihat pada seluruh peserta didik sudah melaksanakan shalat dengan berjama'ah di masjid yang ada di SMP IT Al Khoiriyah Garut. Dari hasil observasi tersebut dapat dikatakan bahwa pembiasaan yang baik selalu senantiasa ditanamkan pada seluruh peserta didik SMP IT Al Khoiriyah Garut , selalu ditanamkan oleh para aparatur sekolah yakni oleh seluruh dewan guru dan semua yang ada disekolah.

f) Menghafal al-Qur`an beserta terjemahnnya dan Hadist Nabi

Dari hasil observasi dapat disimpulkan bahwa pembiasaan perilaku baik selalu ditanamkan di sekolah ini. Dari mulai menghafal Al-Qur`an (tahfidz), lalu menghafal terjemahannya (Tarjim), dan juga seluruh peserta didik maupun tenaga pendidik wajib menghafalkan beberapa surat yang telah ditentukan oleh seorang guru dan pihak sekolah, peserta didik telah ditanamkan dan diajarkan mengenal Al-Qur`an dan menghafalkan nya, bukan hanya peserta didik saja, melainkan seluruh dewan guru juga sama harus mempunyai hafalan Al-Qur'an. Selain itu, para peserta didik juga belajar dan mengamalkan do'a- do'a harian, serta menghafalkan beberapa surat yang sudah menjadi kewajiban peserta didik dalam memenuhi salah satu syarat kenaikan kelas, dari sinilah terlihat bahwa memang benar bahwa di SMP IT Al Khoiriyah Garut ini bukan salah satu pondok pesantren namun sekolah yang dapat menyediakan dan menghadirkan pembelajaranya seperti didalam pondok pesantren, yang menaungi pengetahuan Islami serta aplikasinya dalam kehidupan sehari-hari.

Agar prilaku peserta didik menjadi lebih baik lagi, maka perlu disempurnakan dengan empat akhlak dalam pembelajaran, di antaranya:

1) Peserta didik harus mempunyai tujuan menuntut ilmu dalam rangka menghiasi jiwa dengan sifat keimanan, mendekatkan diri kepada Allah.

2) Peserta didik harus tabah dalam memperoleh ilmu pengetahuan dan sabar dalam menghadapi tantangan dan cobaan yang datang.

3) Peserta didik harus ikhlas dalam menuntut ilmu dan menghormati guru atau pendidik, berusaha memperoleh kerelaan dari guru dengan mempergunakan beberapa cara yang baik.

4) Peserta didik harus berusaha dengan sungguh-sungguh (berjihad) dalam menuntut ilmu serta diiringi dengan do'a kepada Allah agar berhasil dalam menuntut ilmu (Irawan. M. W, 2018:97). 


\section{PENUTUP}

Berdasarkan perumusan masalah dan pembahasan yang telah di paparkan di atas, penulis dapat memperoleh kesimpulan sebagai berikut:

1. Tujuan Penanaman Nilai-nilai Karakter Islami Melalui Program BPI (Bina Pribadi Islam) di SMP Islam Terpadu AlKhoiriyyah, yaitu untuk menumbuhkan kebiasaan Islami dan akhlak yang baik yang sesuai tuntunan ajaran Islam bagi siswa secara kontinu dalam kehidupan sehari-hari agar nantinya siswa siap terjun ke masyarakat sebagai generasi unggul yang cerdas, mandiri dan religius/spiritual. Sedangkan program BPI di SMP Islam Terpadu AlKhoiriyyah, yaitu Pembelajaran Tahsinul dan Tahfidzul Qur'an, Program Ekstrakurikuler, Penambahan Muatan lokal, Kegiatan Sekolah Orangtua, Program Pesantren yang di asramakan

2. Implementasi penanaman Nilai-nilai Karakter Islami melalui Program BPI (Bina Pribadi Islam) di SMPIT Al Khoiriyah dengan menggunakan pendekatan pembinaan keteladanan, pembinaan dengan pembiasaan, dan pembinan dengan nasihat yang masuk kedalam program, dan masuk dalam waktu pembelajaran.

3. Hasil pembinaan karakter berbasis nilainilai Islami di sekolah ini berdampak positif dengan bertutur kata dengan bahasa yang sopan dan berbuat baik terhadap orang lain, senantiasa menutup aurat, belajar amar ma'ruf nahi mungkar, melakukan wudhu dengan tertib dan benar, melaksanakan shalat berjama'ah, menghafal al-Qur'an beserta terjemahnnya dan hadist Nabi yang di aplikasinya dalam kehidupan sehari-hari.

\section{DAFTAR PUSTAKA}

Abuddin Nata. (2003). Manajemen Pendidikan, Mengatasi Kelemahan Pendidikan Islam di Indonesia, Cet. KeIII. Jakarta:: Prenada Media Group.
Aisah. S. (2019). Peranan Mentor Bina Pribadi Islam Dalam Meningkatkan Kecerdasan Spiritual Siswa Kelas Viii Smp It Bina Insani Metro Tahun Pelajaran 2018/2019. . Jurnal Pendidikan Institut Agama Islam Negeri Iain Metro.Vol 5 No2, 54.

Dokumentasi SMP Al Khioiriyah Garut 2019. Furqun Hidayatullah. (2010). Pendidikan Karakter: Membangun Peradaban Bangsa,. Surakarta: Yuma Pustaka.

Habibah, S. (2015). Akhlak Dan Etika Dalam Islam. Jurnal Pesona Dasar, 1(4), 73-74.

Irawan. M. W. (2018). Konsep Pendidik Dan Peserta Didik Menurut Abuddin Nata. Jakarta: Universitas Islam Negeri Syarif Hidayatullah.

Johansyah. (2018). Pendidikan karakter dalam islam; kajian dari aspek metodologi. Jurnal Ilmiah Islam Futura Volume XI, No. 1 ,.

Judiani., S. (2010). Implementasi Pendidikan Karakter di Sekolah Dasar Melalui Pengatan Pelaksaan Kurikulum, . Jurnal Pendidikan dan Kebudayaan Volume 16 Edisi Khusus III. Oktober Balitbang Kementerian Pendidikan Nasional.

Juraini, F. H. (2018). Pembinaan Akhlak Terhadap Siswa Dalam Proses Pembelajaran di SD Negeri Unggul Lampenerurut Aceh Besar. . Jurnal Ilmiah Pendidikan Guru Sekolah Dasar Vol, 3 No (2), , 37.

Marzuki. (2015). Pendidikan Karakter Islam. Jakarta: Amzah.

Mhd. Aulia Firman Puldri. ( 2017). Penanaman Nilai-nilai Karakter dalam Pendidikan Agama Islam melalui Metode Bercerita di SDN 07 Sumanik Kecamatan Salimpaung Kabupaten Tanah Datar, . Jurnal al-Fikrah, Vol. V, No. 1 Januari-Juni.

Mulyasa. (2012). Manajemen Pendidikan Karakter. Jakarta: PT Bumi Aksara.

Musianto, L. S. (2002). Perbedaan Pendekatan Kuantitatif dengan Pendekatan Kualitatif dalam Metode Penelitian. Jurnal Manajemen \& Kewirausahaan, 4(2), , 123-136. 
Wati Karmila, dkk: Penanaman Nilai-Nilai Karakter Islami melalui Program BPI (Bina Pribadi Islam) di SMP Al-Khoiriyah Garut

Raco, J. R. (2010). Metode Penelitian Kualitatif Jenis, Karakteristik, dan Keunggulannya. Jakarta: Gramedia Widiasarana Indonesia.

Wasit Aulawi. (2017). Efektivitas Program Bina Pribadi Islami dalam Membentuk
Karakter Siswa di SMP Islam Terpadu Al- Qudwah Kabupaten Musi Rawas . jurnal Pendidikan, Vol 6. No. 1.

Zubaedi. (2011). Desain Pendidikan Karakter. Jakarta: Kencana. 